\title{
Principles of Resistance in Gharbi Mustafa's What Comes with the Dust, Goes with the Wind
}

\author{
Khorsheed Mohammed Rasheed Ahmed ${ }^{1}$, Hishryar Mohammed Ameen ${ }^{2}$, Kawyar Yaqob Ahmed ${ }^{1}$ \\ ${ }^{1}$ Department of English languages, Faculty of Humanities, University of Zakho, Kurdistan Region-iraq. \\ ${ }^{2}$ College of Education-Akre, University of Duhok, Kurdistan Region-iraq.
}

Received: 07. 2021 / Accepted: 08. 2021 / Published: 09. 2021 https://doi.org/10.26436/hjuoz.2021.9.3.716

\begin{abstract}
:
This paper examines the principles of resistance in Gharbi M. Mustafa's novel titled What Comes with the Dust, Goes with the Wind (2017). It is mainly an attempt to focus on the inner and outer enegertic power to a person in the hard times and shows the major principles of resistance along with its significance for survival This study primarily provides an introduction to the research statement and problem of the study. Concerning the methodology, close reaidng is used as an approach to conduct the study, besides, it further deals with an introduction to the origins of the Yazidi people and religion. The second section of the paper introduces the critical overview, which summarizes the findings of a number of studies related to the sufferings of the Yazidis' females during their captivity by several researchers. The central section provides the various forms of violence used against the Yazidis' females and the impact of their wills and power, and their resistance to survive. In addition, the conclusion of the study concludes the findings of the research.
\end{abstract}

Keywords: Yazidi People, Captivity, Resistance, Self- Confidence and Individual Empowerment, and Faith and Trust.

\section{Introduction}

Gharbi M. Mustafa has remarkably attracted readers from different parts of the world to the Yazidis' cause as a social issue. This research paper deals with the principles of resistance in this novel What Comes with the Dust, Goes with the Wind. According to Knowles and Linn (2004), the term resistance can be defined as the act of dissenting, withstanding, or delaying motion (p. 4). The novel as a modern one was self-published in 2017. It is based on personally conducted interviews with the Yazidi women who have escaped ISIS (The Islamic State of Iraq and Syria) revealing their dreadful experiences. It is a thrilling and powerful literary work, rich in culture and characters, displaying the genocide and the will for the survival of the Yazidi people. The novel mostly focuses on the females and their unconquerable persistence for survival in the face of unbearable difficulties. Regardless of the author's Kurdish nationality, he has written the novel in the English language to shed light on the tragic story of the Yazidi people for the world to acknowledge in a way that the international news could not.

Seemingly, ISIS organization had conducted war against people. However, However, many people might not be aware of their acts against the Yazidis, particularly in the Sinjar district of Iraqi Kurdistan in 2014. Mustafa, through his realistic novel, tries to turn the world's attention to the unjustness practiced against them. Yazidi people had contributed to the writing process for it helped the writer to sincerely present the brutal reality that they experienced. This study is an attempt to bring about what has been practiced against the Yazidis in Mustafa's novel. It particularly focuses on the females' resistance and considers it as a social issue against them based on religious distinctions.

This study aims at identifying the principles of resistance in Mustafa's What Comes with the Dust, Goes with the Wind by focusing on Yazidi females in particular in their survival from ISIS captivity. It also tackles the impact of their will and pride as driving force in the face of numerous obstacles and unimaginable difficulties. Finally, it sheds light on the so-called "Islamic State" by realistically displaying their beliefs and actions in the novel.

\section{The Brutality of ISIS against the Yazidis}

Yazidis are one of the ethnic and religious communities' aboriginal to the Middle East. Substantially, the majority of Yazidis live in the northwest of Iraq, in areas surrounding Shingal Mountain and Shekhan territory. There are some Yazidi villages and towns in Talkeef and Bashiqa District, and in Duhok Governorate into the interior of the Kurdistan Region of Iraq (KRI). However, the community is about 550,000 - 600,000 Yazidis approximately in Iraq. Yazidis are considered the second largest national-religious minority in Iraq, posterior to the Christians. Along centuries, Yezidism counted on conveying its ideology and beliefs through verbal heritage in the form of poetry, hymns, and stories rather than scripture. Originally, the Yazidi language of religious books, texts, prayers, and songs is Kurmanji Kurdish. Remarkably, it is widely acknowledged that the original language of the Yazidi community is Kurdish, but many also speak Arabic because of their proximity to Arab neighborhoods and Ba'athist Arabization campaigns. However, Yazidis share a strong love and connection to their land and geographic location, especially their main temple in Lalesh, as it is built in the 
place where Yazidis believe creation began after the Great Flood (Zoonen and Wirya, Pp. 4-8).

Many governmental reports and research studies have discussed the traumatic experiences the Yazidis went through at the hands of the self-declared Islamic State. Some research findings have summarized the patterns of violence used against them, the aftermath of their ordeal and have analyzed their psychological states. For instance, two research studies were conducted using surveys; the findings Outlined ISIS use of violence as a weapon of war and as a means for religious and organizational policy practices (Merani Pp. 3, 22; Bitar Pp. 1, 56). Another study done by Revkin and Wood refers to many reports that describe ISIS's patterns of violence as indiscriminate. Their research indicates that they are more complex and systematic. Although ISIS published many fatwas and texts as justifications for subjecting Yazidi women, at the same time, they prohibited attacking Sunni women, and thus the organization's intentional targeting of this specific group with specific forms of violence remains an unsolved puzzle by the existing theories.

A study had interviewed fifteen females between the age of eighteen to sixty-five and a report conducted on twenty Yazidis of different genders and ages, in some of the refugee camps throughout the Kurdistan Region (Zoonen and Wirya Pp. 4, 10). the participants openly discussed the forms of violence used against them such as; forced conversions, abduction and slaughtering children and old women, sexual enslavement of the virgins and the beautiful females and using them as rewards presented to ISIS Amirs and suicide bombers. Moreover, this organization has employed human trafficking not only as a means of war but also as a means of ethnic cleansing (Holz, p. 14). Hence, the findings of the study highlighted the media's bias for the young and unmarried women, overlooking the suffering endured by men, the elderly, children, widows, and married women. A survey study research by Kizilhan et al., focuses particularly on the psychological conditions of the survivors (Pp. 2-3). The findings show the high rates of depression and post-traumatic disorder they are suffering from and the challenges they face in their lives. The majority of female survivors were rejected by society as shown in a research done by Speckhard and Shajkovci. Their research highlights the unprecedented societal hurdles and unacceptable reality of the Yazidi rape victims that made them heart-pierced for considering them as social stigma likely from the close social groups. Thus, bearing children with ISIS fathers causes the mothers to face the heartbreaking choice of abandoning their children.

These recent studies, along with the realistic novel by Gharbi Mustafa provides insights into the horrific experiences the Yazidis, especially females, went through under ISIS's captivity as well as the difficulties in coping with those dreadful experiences. Thus, this study is an attempt to fill a gap by focusing on the atrocity of the ISIS practice against the Yazidi people in Mustafa's novel that is based on real events. Besides, this article particularly concentrates on both females and male character's powerful principles of resistance to survive the hardships during their captivity and the effects of the ISIS group have had over their lives afterwards.

\section{Resistance}

Resistance is a behavioral outcome, the act of withstanding influence. However, the core definition of resistance is that it is a penetrative reaction against change. Although resistance is a response to pressure for change, the source of resistance is sometimes attributed more to the person, and sometimes it is attributed more to the

situation.

"Resistance could be understood as a response to power from below

a subaltern practice that could challenge, negotiate, and undermine power" (Baaz et al. P. 60) Michel Foucault in The History of Sexuality (1978) states that it requires for being a specific stage of freedom in a condition that the power can activate forcefully. there are some theoretical properties of resistance that distinguish it from other similar forms of political actions. Resistance is a reaction against power with all its forms, relations, and claims by power or violence, when occurring as a power strategy (Baaz et al. P. 60). According to Scott (1985), classic categorization, mentioned, here called public and disguised resistance, are related to three forms of domination (material, status and ideological), resulting in six various types of resistance including; position, land invasion, demonstration, stand opposed material domination, statement of worth or violation of position and status emblems against status domination. Same thing with ideological motivators goes against ideological domination, and direct resistance by incognito resisters against material domination.

\section{Optimism and Patience}

Positive and negative expectations regarding the future are important for understanding the quality of life. Besides, mental fitness is to be measured by how optimistic people are about themselves and life. The concept of optimism concerns people's expectations for the future. Scheier and Carver (2009) argued that optimism generally remains relatively stable over extended periods, at least in the absence of major life transitions and dynamic situational changes. This raises questions about whether procedures such as mental simulations can be expected to have pervasive or long-lasting effects from an unpleasant event.

The most known basic meaning of patience is the tendency of a person to wait calmly in the face of frustration, distress, and pain. Patience has been specified as warmly as a nurturing capacity, as sterile as a long-term reward response, and as vaguely as simply the behavioral act of waiting. It considers wrapping fortitude and self-judge fortitude of human beings against problems and pains. According to Blount and Janicik, patience is a reaction to delay; it reflects emotions like calmness, sympathy, and empathy. According to McClough et al., patience is a form of wisdom, it demonstrates that we understand the fact that sometimes things must unfold their 
own time and teaches us to deal with situations that are out of our control (Bülbül and Arslan Pp: 1632-1645). Optimism and patience are constant themes found in the first chapter of the novel. The novel is told through a third-person omniscient view and it starts with the main character Nazo attempting to end her life, but then the plot moves to the past where "Her mind drifts to the August afternoon five months ago when she'd walked into the courtyard of her family's farmhouse" (Mustafa, p. 2). The flashbacks take the reader to the time when Nazo was happy, full of hope and optimism, and was planning a whole life with her lover Azad.

First, introducing the concept of patience through Nazo and Azad's character to Nazo, meeting Azad, the substitute teacher, was the pinnacle time of the day, which she impatiently anticipated. Her father was the headmaster, and so "delivering her father's lunch became Nazo's sacred mission" (Mustafa, p. 4). However, these rendezvouses developed to an elopement to marry and live somewhere away from the village. "For reasons of her own, she longed to fetch more water from the Bira Zeytona well" (Mustafa, p. 2). Fetching water was her excuse to meet Azad before their escape, which soon developed into something more. Her impatience not only presented in seeing Azad but actually in giving herself to him before their marriage. It is in her desperate want "to leave the village and never come back" (Mustafa, p. 3).

Similarly, the trait of patience, as well as impatience, exist in Azad's character. As days passed, he grew more impatient to leave the village because apart from his big dreams that never fit in the village, "Staying in the village would mean, at best, a life in chains for him and Nazo" (Mustafa, p. 14). He has constantly resisted accepting the lifestyle in the village as his reality and was aware of the fact that staying in the village means they can never marry due to the social norms. Therefore, he tells Nazo "The Daesh keep drawing nearer to our villages. I have to check on our arrangements. "By tomorrow's sunset, we will breathe in a safer land" (Mustafa, p. 7). This quote shows that he did not only willing to have a better life outside the village, but he was trying to save himself and Nazo before the arrival of ISIS.

The second concept is optimism which oftentimes turns into pessimism. Nazo tries to be optimistic and hopeful of their lives to get better as she tells Azad "Can't we bring colours into our lives here?" (Mustafa, p. 6). This quotation shows her desperate attempt to live a normal life with the person she loves and not having to bring her family disgrace by her elopement. It also shows her inner conflict, she is torn between wanting to be the dutiful daughter and marry her cousin as planned without resistance and between following her heart and eloping with Azad. Before meeting Azad, Nazo's life was shallow, a circle where she would go in constant motions without reaching anywhere, but to her, Azad was "a sweet apple from the forbidden tree" (Mustafa, p. 4). He was different from other young men in the village, and that is exactly what captured Nazo's attention and stole her heart. All her life, the only thing she learned from her family was accepting her destiny and protecting her family's honor by marrying her cousin as a tradition.
This deprived her of her right to dream and be optimistic about what the future will bring to her. She was never taught nor experienced resistance. However, with Azad, she started dreaming and spreading her wings, love taught her optimism, optimism for desiring a new life in a new land.

Likewise, Azad was suffering from inner conflict, as he was both an optimist and a pessimist. He has always viewed life in the village pessimistically; he has never tried to fit in with the villagers and their lifestyle as he tells Nazo "Life here is like sitting inside four walls and watching the world on an old black-and-white TV" (Mustafa, p. 6). Meeting Nazo gave him a bigger reason for desiring change. He was delighted with the idea of elopement, but two things worried him; being caught by the villagers eloping with an engaged girl and escaping by a boat.

Ever since he was a child, Azad has always feared the water. However, his love for Nazo has given him the courage to end this conflict, and as the author puts it "Neither water nor dust would destroy his dream of a free life with Nazo at his side" (Mustafa, p. 15). Her love has provided him with the strength he desperately needed to finally take the first step towards his dreams because to him "life was not about what he was supposed to do, it was about doing what he loved" (Mustafa, p. 15). If Azad has decided to turn himself into a version that would be acceptable among the villagers and started to accept his destiny, he would lose the most valuable thing in his life, Nazo. He would not be able to marry her as she was to wed her cousin and "for their love to blossom, they must break free from their people and travel to the farthest lands in a search of a place to build their home" (Mustafa, p. 15). Thereby, their escape was the only way for them to blossom together. His grandfather also provided him with his blessings and encouraged him if he wanted to be happy, he must dare and act crazy and "never expect Narcissus to blossom in a desert" (Mustafa, p. 15). This final push towards optimism was enough to take away any doubts left from Azad's heart.

While Nazo and Azad were planning a happy life together, distress tormented the character Omed. All his life, Omed has been suffering from loss and loneliness. Years before, he lost his mother and then the rest of his family to a suicide bomber. However, like Azad, Nazo has been his hope for a happy life. For years, he has been cutting himself to cover the pain in his heart. But he hoped loving Nazo could be his chance for change. "Omed followed Nazo every time she fetched water from the well or went to the melon farm. He woke up early that morning and wrote a love letter to her" (Mustafa, p. 18). After finally having the courage to confess and waiting for her with hope and anticipation, his dreams were shattered as he watched Nazo give herself to Azad. "Today had started with such promise, yet anguish shadowed his eyes and hollowed his face" (Mustafa, p. 21). The disappointment took from him any chance of optimism and happiness left, as "Nazo had been his hope for a new family. He could have stopped cutting for her" Mustafa, p. 22). With the crushed hopes and dreams, Omed went straight back to cutting. He knew it could not bring Nazo back, but cutting because of her would make her a part of his body. "Not only were beautiful things 
painful, but painful things were also beautiful” (Mustafa, p. 22). This quote best describes his relationship with Nazo. She was the only beautiful thing he had or wished for, but his love for her caused him pain more than any physical pain cutting could cause. Nevertheless, cutting gave him temporary relief as "it allowed him to forget, for a few moments, the shattering image of his love and her lover. The pain over his heart lessened the pain inside his heart" (Mustafa, p. 23). This again brought him back to the hole of despair and led him to give up on the only thing that caused him to resist the urge for cutting and hurting himself. He again lost his only chance for happiness and love and all turned to disappointment and despair.

\section{Self- Confidence and Individual Empowerment}

Building self-confidence is a matter of a long process. It is something that takes time, perhaps years, as it may take some time to become open, recognizing the blind spots that hold us back from self-awareness. Generally, self-confidence is a mental or psychological condition of a person who gives strong confidence in him or her to perform any act. A study conducted at the University of Florida Counseling Center states that self-confidence is firm and such a prestigious attitude about one's skills and abilities. It means you accept and trust yourself and have a sense of control in your life and can handle any strict or hysterical criticism. (Greenacre, Tung, \& Chapman, P. 169-180).

Nazo's character best represents the individual empowerment. Due to her powerful and resourceful nature, she manages to practice different manners of defense. Amid the terror and fear caused by ISIS men, seeing Azad makes Nazo feel as if "time stood still and mute. All of Nazo's fears and worries evaporated like a dust storm giving way to the first rain" (Mustafa, p. 36). Azad's presence takes her away to a world of pleasant thoughts, forgetting the reality for a few seconds. This temporary reassurance provides Nazo with empowerment and encouragement that continue throughout the novel, forming a driving force and motivation. Later, Abu Jihad, an ISIS emir, takes Nazo as his share of the war. "He forced her to watch a video of ISIS men strangling a woman to death. He warned her that she would suffer the same fate if she disobeyed him or showed resistance" (Mustafa, p. 41). Terrified, Nazo's mind goes blank, and she could not perform any forms of defense and resistance. She feels weak and broken as he forces her into the bedroom. "O' Khuda, Supreme God, blow the breath of life into me and grace me with a new soul" (Mustafa, p. 42). Devastated and drained, Nazo pleads for God to grant her a new soul and take away the contaminated. She longs to visit the Sacred Lalish Temple. "Bathing in ZamZam water would purify her soul." "Then she would make her only wish: to see Azad again" (Mustafa, p. 43). With her damaged soul and tainted body, seeing Azad again is the only empowerment Nazo longed for.

After reuniting with her younger sister, Nazo's motivation and responsibility increases, as she was ready to form all possible tricks and manners to save her sister. Most of the captive girls refuse to eat or even shower to avoid being taken. Nazo on the other hand, instead of submitting, "thought on a way to escape from the house" and two other girls agree to join them (Mustafa, p. 55). Opposite to what she encounters earlier, Nazo has learned that the key to survival is motivation and empowerment. To survive, she must not lose her grasp on her life. However, the attempt is failed as her sister injured her leg, and the four girls realize at the hospital that they have escaped without niqaabs. That is resulted in a severe punishment. "Her skin broke; her voice broke; her spirit broke. Soon she could do nothing but lie on the ground and wait for it to end" (Mustafa, p. 57). At this point, Nazo has lost all her power and motivation to defend herself. She is both physically and mentally unable to resist for the incident was unpreventable. She is aware of the punishment awaited if they failed to escape, but she would not hesitate to seize the slightest chance of reaching freedom, and for her, that is an enough motivation.

Self-confidence is as important as individual empowerment, not only to Nazo but also to Omed and Suz. The unsuccessful attempt did not frustrate Nazo as her self-confidence increased and started scheming another plan by taking advantage of Waleed, an ISIS man who wants to marry her. Waleed might be a lifeboat for them. "My dowry is Sarah. ... I want her out of here, back to Kurdistan" (Mustafa, p. 58). She starts thinking smartly and uses Waleed's admiration to her advantage. In addition, this time she succeeded in sending her sister away. Nazo later gets the chance to escape. Sharmeen, a sick girl Waleed takes Nazo to the hospital by her request, offers Nazo her niqab to run for freedom, a chance Nazo gladly accepts.

Self-confidence is presented through Omed and Suz's character as well. "Can I join the YBS?" (Mustafa, p. 72). Regardless of Omed's lack of experience with arms, he decides to join the Yazidi's newly formed army. He is confident about his experience in using the blade, which can serve him with the killing. Similarly, Suz, a Yezidi girl who Omed immediately admired her powerful and confident character. "I will never forget. I will never forgive. I promised myself I would not die until I see my sister again until we go home" (Mustafa, p. 75). Contrary to Nazo, Suz was in the army and had the chance to take part in the killing of the ISIS men. Hatred filled her because of her sister's captivation with ISIS. Contrary to Nazo, she never experiences the horror of raping, sexual trading, and sexual violence. Like Nazo, the source of her power and defense is saving her sister. However, their trait of self-confidence differs in the fact that Nazo's situation requires a significant amount of motivation and resistance to survive in the face of intolerable situations. Whenever she is close to losing the will to live, she manages to rebuild her confidence, and thus enable her to continue in her quest for survival. Thus, her powerful self-confidence enables her to resist against the difficulties she cautiously faces

\section{Faith and Trust}

Faith, especially relating to religion and spirituality, is a fundamental, multidimensional and multilevel aspect of humanity. Faith has always had a powerful and distinct impact on a person's functional and dysfunctional mental processes, their emotional and intellectual states, 
behaviour, and attitudes, while on the societal level, it has been provided the requirements for the formation of identity, social stability, social roles and control, and moral order. Spirituality is the basic principle of faith which is intensely personal and often seen as extremely private. Hellwig explains that the term faith differs in meaning from religious perception to a certain set of beliefs (p. 3). Spirituality and religion can take a direction that may plot them to be closer together and heading in the same direction which is a calm realm and peace into the person's inner self (What is Faith 2014).

The other concept or theme that later determines the course of the actions and events of the novel is trust. Trust is as regular, honest, and cooperative behavior that is deeply embedded in a social context. Trust, according to Anthony Giddens (1991), is endowing confidence in people or things, putting faith in them by omitting ignorance or lack of information (p. 244). Hence, Trust is the fundamental aspect of the human beings that related to various connections. It manages the interactions among people. It can be stated that the concept of trust enhances the power of faith to create the motif so as to get a spiritual power for resisting the obstacles in the hardship of life.

After escaping from Waleed, Nazo found herself alone in Mosul. At this point, trust forms a matter of life and death, survival, and downfall. She was aware of the fact that she could not trust anyone; therefore, the first two people she asked for help were a "white-haired old man" and a Muslim. However, they both were not of any use for the fear of the ISIS men. By mischance, a young man emerged and offered his help, claiming that "[she has] You've found the right person" (Mustafa, p. 79). Besides, Nazo is realized by a lady in the story how unlucky she is, "[she] must be ill-fated; of all the men in Mosul, [she] came across this useless son..." (Mustafa, p. 80). The woman's words turned into reality as instead of taking Nazo to Mount Shingal, he sells her to a slave dealer. With the realization of trusting the wrong person, "Nazo struggled to stay on her feet. ... she toppled to the ground" (Mustafa, p. 83). Ascertained that all of her efforts go in vain, a consequence of her false estimation, Nazo feels disheartened. However, she has resisted to get motivated by her spiritual power in her path.

Being a sex slave again, Nazo encountered an unpleasant situation mixed with pleasant news. "Sir, this girl isn't a virgin; she's pregnant" (Mustafa, p. 85). Before Nazo could react and absorb the news, the slave dealer started whipping her with all the power he had, as that news meant she has just caused the loss of a great amount of money. "In a few moments, her tears stopped, and a smile curved her lips as she imagines herself caring a blue-eyed baby in her arms, blue eyes like Azad's. At that moment, there are billions of voices flying across the universe, but she is immersed in her baby's first laugh. The giggles breathe life into her, and that alone is reason enough to live" (Mustafa, p. 87). At the current juncture, faith is the only manner of defense and resistance Nazo possess, inducing the will to survive for the sake of her child, the only thing that is left from Azad. "Then her face cloudes as the color of the baby's eyes turned to black and a long beard trailed down the baby's bare chest. Dark thoughts crept into her mind" (Mustafa, p. 87). Her mind goes back and forth between happiness and misery, between the happiness of caring for Azad's child and the possibilities of caring for an ISIS child. This doubt is frustrating enough to lead her, for the first time, to try to end her life. Yet, the attempt failed. Even though Nazo tries to cut her wrists, but the cuts came shallow. This may imply that, regardless of trying, deep down she has a faith that this child possibly embodied into a happy resolution for her. Therefore, no matter how frustrated she is, she could only be hopeful that the child is Azad's one.

Later, Nazo is once again sold to an Egyptian old man. "You're here to take care of my daughter. She's possessed by a jinni" (Mustafa, p. 94). Remembering the story of her grandfather talking to a jinni, an idea comes to her mind. "If she speaks to jinn, she might be able to summon a jinni who can tell me the colour of my baby's eyes" (Mustafa, p. 95). This unusual way of reassuring her doubts manifests Nazo's desperate condition. She is ready to take any possible chance that could fill her with faith, the faith to have a reason to resist and survive. "I was faking" (Mustafa, p. 103). However, Nazo's mere hope to gain spiritual power is once again destroyed. obliterated. All the same, Nazo gets another chance to bolt for freedom. Things appear to be different and more promising this time as Mirvat, the Egyptian's daughter is as desperate as Nazo to escape from the house. "You an' me, Nazo, we're getting the hell out of here. No way am I gonna be some twisted trophy bride" (Mustafa, p. 104). Their plan is succeeded and they leave the house, but Nazo's hopes are once again crashed as she is put in jail by Hezbah policemen. Nazo doesn't dare to tell the truth knowing it couldn't grant her freedom and gaining strength from her child, she tells them "My owner was a Libyan from Dayrzoor and was martyred in battle" (Mustafa, p. 108). This leads Nazo to be held in a jail till they've found a buyer.

\section{Challenges and Struggles}

Challenges are considered as the factor of finding strength toward developing learning lifetime within its two main types of situational (external) and dispositional (internal) ones (Laal \& Laal, 2012). Life is full of struggles as every person is struggling to reach and attain something in the face of complications. According to Cambridge University, the term struggling means experiencing difficulty or striking to achieve something that is not easily achieved. The comprehensive struggle of humanity through the route of history for the attainment of various shapes in the various fields of activity is evidence that life is entangled in the uneasiness of the human spirit, which is clever to overwhelm its confederation of action and restrictions of being understandable (Krishnananda 2018).

The Yazidi people have witnessed countless catastrophes from the beginning of their existence. It was mainly for religious reasons because the Yazidis form one of the ethnic minorities. Suz states that, "They've massacred us for hundreds of years; now they lop off our heads and plant us in the ground. They forgot we have roots. We always grow again, yet we always live at the mercy of others. Nobody will protect us; we must take up arms and defend ourselves" (Mustafa, p. 118). She brings out the 
Yazidi people's will and resoluteness in the face of ruthless enemies, the challenges and struggles caused by them. Nevertheless, the Yazidis have yet learned to develop resistance, defense, and self-dependence. She further adds, it is the right time for them to learn from the past and act, that it is the time to strive for their lives. For Nazo, with Preservation comes a lot of responsibilities, struggles, and challenges. In the beginning, she was only trying to persevere in her life and her sister. Nevertheless, with her pregnancy, things became more complicated, which added another burden for Nazo to struggle. Additionally, throughout the novel, Nazo has constantly been trying to keep Azad's faithful love alive in her heart regardless of the circumstances and all of her attempts and endurance were for the hope of reuniting with him. This is obvious near the end of the novel when she replies to her new buyer when informed her of their marriage, "I am still married; my husband is on Mount Shingal" (Mustafa, p. 128). The idea of reuniting with Azad and bearing his child serves as an impulsive force for Nazo that keeps her body and soul together. Yet she was hit with an abrupt shatter of dreams and hopes. "Your mother was shot dead in Telafar for spitting in her owner's face. Your Azad was killed before he made it to the mountain together with your father" (Mustafa, p. 128). With this realization, Nazo's world darkened, her soul and heart torn into pieces. She lost faith and hope in happiness, she lost the desire to live. This is evident in the note she wrote to Azad before setting herself on fire "I don't want to breathe in the world when you are not in it anymore. Tonight, I will be your bride. Tonight, I will dance with you under the blue raindrops of Heaven" (Mustafa, p. 130). Her words portray and demonstrate the amount of pain and disappointment she feels.

In the last few months, reuniting with Azad has given her the strength to endure the sufferings and given her a reason to fight for survival. However, destiny has taken Azad along with everything she ever had and wished for, away from her. And thus, it has taken away her strive to live. "Before the fire made contact with the curly hair on her head she felt something magical -a sensation - a motion inside her womb. Another life moved within her!" (Mustafa, Pp. 130-131). Her grief over losing Azad made Nazo shortly forget that regardless of Azad's heart-piercing departure, she still had a part of his left with her. "She had to lick the wounds on her soul and cling to the thin thread of her life for the little life inside her" (Mustafa, p. 131). The realization of their love never survived and it broke her heart, but now she has a new reason to live for, another love and possession to protect, her child. Thus, the child symbolizes their eternal love, which even death could not end. The child's life represents the continuity of their love. She realized that for that to happen, she must "weave her torn parts back together as best as she could. Her heart would resemble a patchwork quilt, but it could still make a warm home for her child" (Mustafa, p. 131). "Like the shooting stars, she was wrecked, broken into pieces, but she intended to shine brightly as she fell" (Mustafa, p. 136). Having new dreams and hopes, Nazo flew for freedom. With her sister, and now her child, Nazo's determination grew more than ever.
It is said that there is always a light at the end of the tunnel, and this is very true for Nazo. After all the suffering and difficulties, Nazo finally gets the chance of salvation. "Nazo burst into fresh tears as she realized she was about to fulfill Azad's long-waited dream" (Mustafa, p. 166). Living abroad, where they could live freely with no costumes and traditions to stand in the face of their love, was Nazo and Azad's ultimate dream and goal. Nonetheless, that goal is now one step away from being achieved, but to Nazo, it is not the same without Azad. Another long-waited desperate hope is to be fulfilled, which Nazo has been longing for from the start of the novel, is caring Azad's child. "Blazing dark-blue eyes peered from the blanket while a smirk curled his lips. With a triumphant wail of heartbroken joy, Nazo released the mountain of despair that had dwelled in the depths of her soul for the last nine months" (Mustafa, $p$. 169). For Nazo, this was the ultimate triumph after everything she has been through. The fear of not caring a part from Azad but rather the enemy had been a living nightmare for her, which she is finally relieved from. Therefore, challenges are used as a tool to overcome the personal and social problems in the novel that leads the main character Nazo to be as hopefully resistant as she could for her future baby. "challenge here as restoring the idea of resistance to change to a nonblaming perspective" (Krantz P. 44)Conclusion

The Yazidi people's perseverance is proved to be indomitable, which Gharbi Mustafa has effortlessly illustrated throughout the novel. It is best presented through Nazo's character and her persistence. This thrilling and powerful novel by some means displays the religion, costumes, and traditions of the Yazidis. It further revealed the genocide held against them and their undefeated spirit and will.

Generally, the resistance of the Yazidi people is valued throughout the novel and this can be seen in the last few chapters which detail the outcome of the characters' predominance over abhorrent circumstances. Furthermore, the novel exposes the false beliefs of ISIS and portrays them as a forged group fighting for personal benefits, both on the level of financial as well as sensual, far from religious purposes.

The findings prove that a person's will and endurance can be tested by the number of struggles and challenges one faces. That with tenacity comes survival and peace. The findings generally show that after all the sufferings and difficulties, the main characters are rewarded for their persistent resistance. The rewards, however, come with shortcomings as the long journey of survival broke some things and took away other things. Both Nazo and Suz reach safety, but that safety came with a great price. And thereby, the departure of ISIS didn't completely erase their traces and ruins they had caused.

\section{List of References}

\section{Primary Source}

Mustafa, Gharbi M. What Comes with the Dust Goes with the Wind. Peacock Publishing, 2017, Print. 


\section{E-Sources}

Scott, James C. Weapons of the Weak: Everyday Forms of Peasant Resistance. Yale University Press, 1987, Google books.

Hellwig, M. K. A History of the Concept of Faith. In. M. Lee (Ed.), Handbook of faith. Birmingham, AL: Religious Education Press, 1990.

Knowles, Eric S., and Jay A. Linn. Resistance and Persuasion. New Jersey: Lawrence Erlbaum 2004. Google Books. Web. 4 Dec. 2020.

Foucault, Michel. The History of Sexuality. Vol. 1, Pantheon Books, 1978. Web.

\section{Journal Articles}

Blount, S. and G. A. Janicik. "What makes us Patient? The Role of Emotion in Sociotemporal Evaluation." Unpublished Manuscript: University of Chicago. 2000.

Baaz, Mikael, et al. "Defining and analyzing "resistance": possible entrance to the study of sub revise practice." Alternative Global, local, political 41(3), (2016): 137-153. ResearchGate. https://www.researchgate.net/publication/31608 7102 Defining and_Analyzing_Resistance_Pos sible Entrances to the Study of Subversive P ractices

Bülbül, Ayşe Eliüşük, and Coşkun Arslan. "Investigation of Patience Tendency Levels in Terms of SelfDetermination, Self-Compassion, and Personality Features." Universal Journal of Educational Research. 5(9), (2017): 1632-1645., doi:DOI: 10.13189/ujer.2017.050921.

Revkin, Mara, and Elisabeth Wood. "The Islamic State's Pattern of Sexual Violence: Ideology and Institutions, Policies, and Practices." Journal of Global Security Studies, 2020, doi:10.1093/jogss/ogaa038.

Scheier, Michael F., and Charles S. Carver. "Dispositional Optimism and Physical Health: A Long Look Back, a Quick Look Forward.” American Psychologist. 73(9), (2018): 1082-1094., doi:10.1037/amp0000384.

Kizilhan, Jan, et al. "Potential Trauma Events and The Psychological Consequences for Yazidi Women After ISIS Captivity.” BMC Psychiatry. 20(256), (2020).

https://www.researchgate.net/publication/34018 8041_Potential_Trauma_Events and the psych ological_consequences_of_Yazidi_Women_afte r_ISIS_Captivity

Krishnananda, Swami. "The Struggle for Perfection: an Analysis of the Structure of Life and the Yoga Way of Universal Integration According to the Bhagavadgita." Divine Life Society, 2018. https://issuu.com/dirkjan2/docs/sri_swami_krish nananda - the strugg Baaz, Ikael, Lilja, Mona, Schulz, Michael, and Vinthagen, Stellan, Defining and Analyzing "Resistance": Possible Entrances to the Study of Subversive Practices. retrieved from:

https://www.researchgate.net/publication/31608 7102_Defining_and_Analyzing_Resistance_Pos
sible_Entrances_to_the_Study_of_Subversive_P ractices [accessed Aug 12 2021].

Greenacre, L., Tung, N.M. \& Chapman T. (2014) 'Self Confidence and the Ability to Influence', Academy of Marketing Studies Journal, 18(2), 169-180

https://www.researchgate.net/publication/286318041_S elf_confidence_and_the_ability_to_influence

Laal, M., \& Laal, A. (2012). Challenges for lifelong learning. Procediasocial and behavioral sciences, 47 ,

1539 -

1544.https://ieeexplore.ieee.org/document/935 7045

Krantz, J. (1999). Comment on Bchallenging 'resistance to change'^. The Journal of Applied Behavioural Science, 35(1), 42-44

https://www.researchgate.net/publication/211389315_C omment_on_Challenging_Resistance_to_Chang $\mathrm{e}^{\prime}$

\section{Websites}

Bitar, Sali. "Sexual Violence as a Weapon of War: the Case of ISIS in Syria and Iraq." Uppsala University, 2015, $\quad$ www.divaportal.org/smash/get/diva2:889178/FULLTEXT 01.pdf.

Cambridge Dictionary. "Citation In Cambridge Dictionary." n. d. Retrieved April 12,2021.Fromhttps://dictionary.cambridge.org/di ctionary/english/challenge

Cambridge Dictionary. "Citation in Cambridge dictionary." n. d. Retrieved April 3, 2021.Fromhttps://dictionary.cambridge.org/dicti onary/english/optimism

Carver, Leo. "The Importance of Patience in Every Area of Life." Chopra, Personal Growth, 5 Oct. 2016, 12:52 PM, chopra.com/articles/theimportance-of-patience-in-every-area-of-life.

Speckhard, Anne, and Ardian Shajkovci. "Yazidi Survivors of ISIS' Cruelty Face Hurdles in Finding

Justice." 2018, www.academia.edu/38014694/Y azidi_Survivors of ISIS_Cruelty_Face_Hurdles in Finding Justice.

UNIVERSITY OF SOUTH FLORIDA COUNSELING CENTER. (n. d). "What Is Self-Confidence?" Retrieved April 5, 2021. From https://www.usf.edu/studentaffairs/counseling-center/top-concerns/what-isselfconfidence.aspx\#: :text=Self $\% 2$ Dconfidence $\% 2$ 0is\%20an\%20attitude, assertively\%2C\%20and\% 20 can\%20handle\%20criticism.

"What Is Faith and Where Does It Come From?" 2014. Retrieved April 4, 2021. Fromhttps://blog.biblesforamerica.org/what-isfaith/

Zoonen, Dave Van and Khogir Wirya. "The Yazidis Perceptions of Reconciliation and Conflict." Middle East Research Institute. 2017. Web. 17 Dec. 2020 https://www.usip.org/sites/default/files/Yaz 
idis-Perceptions-of-Reconciliation-and-ConflictReport.pdf

Merani, Delwin. "Sexual Violence by ISIS The Case of the Yezidis." University of Amsterdam, 2018, scripties.uba.uva.nl/document/659654

Holz, Lisa Marie. "The Role of the Islamic State Terrorist Organization in Human Trafficking."
May 2017 , ezidis.org/wpcontent/uploads/2018/03/The_Role _of_The_Islamic_State_Terrorist.pdf.

Giddens, A. "Modernity and Self-identity: Self and Society in the Late Modern Age." 1991. Polity Press, Cambridge. Web.

\section{بنه ماييّن به ركيرى د رومانا غه ربى مسته فا دا يا بناثى (يا دهيت دگه ل توزىّ دجيت دگه ل باى)}

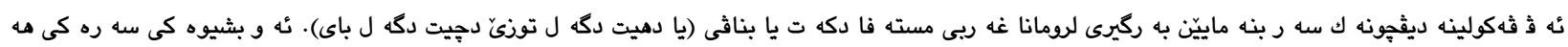

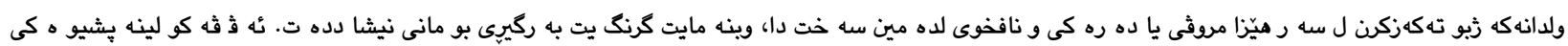

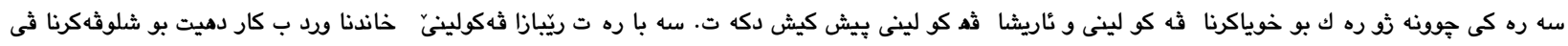

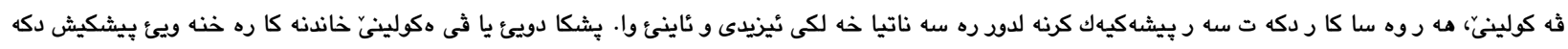

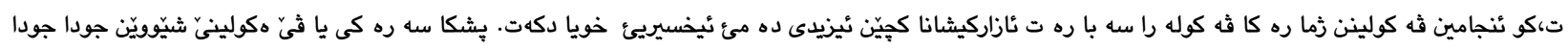

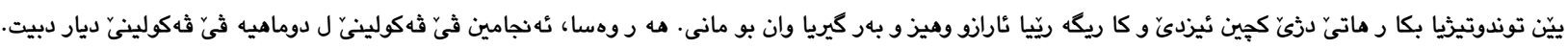

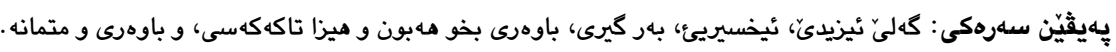

\section{مبادئ المقاومة في رواية "ما يأتي مع الغبار يذهب مع الريح" للكاتب غربي مصطفى}

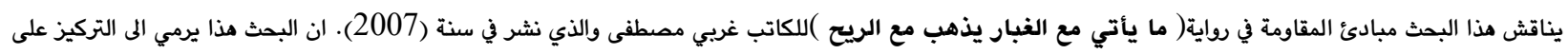

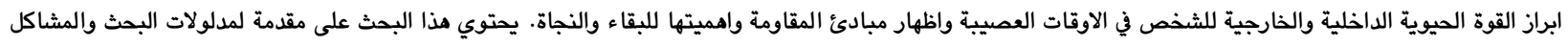

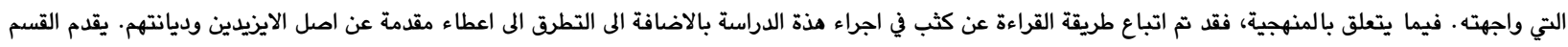

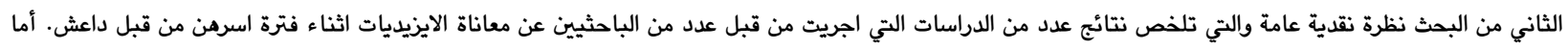

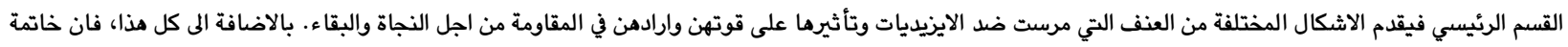
البحث تلخص ما توصلت اليه هذا البحث. الكلمات الدالة: الشعب الايزيدي، الأسر، المقاومة، الثقة بالنفس والتنمية الشخصية، والايمان والثقة 